\title{
Tumbuka Language
}

National Cancer Institute

\section{Source}

National Cancer Institute. Tumbuka Language. NCI Thesaurus. Code C154179.

A Niger-Congo Bantu language spoken in the Northern Region of Malawi and also in the Lundazi district of Zambia. 